\title{
DIVERSIFICATION OF THE DEVELOPMENT LEVEL OF MULTIFUNCTIONAL FARMS FROM THE CENTRAL POMERANIA REGION IN POLAND
}

Danuta Zawadzka ${ }^{1}$, professor; Agnieszka Kurdys-Kujawska², assistant professor

1,2 Koszalin University of Technology, Faculty of Economics, Department of Finance

\begin{abstract}
Diversification of farm income sources is an important way of counteracting the low profitability of farmers' activities. It also contributes to a more efficient use of resources and ensures a long-term stabilization of household income for farmers. The aim of this study is to determine the level of development of multifunctional farms and to indicate which factors influence this development. The study was carried out on a sample of 256 farms in Central Pomerania. We hypothesized that the determinant of development in multifunctional agricultural holdings is the level of diversification of income sources, where higher income diversification is associated with an increase in total incomes of farmers' households and their higher profitability. In order to determine the degree of variation in the level of development of multifunctional farms, a linear ordering method based on Z. Hellwig's taxonomic measure of development (TMD) was used. Information weights were used to determine the factors that had the greatest impact on the studied phenomenon. The results show that multifunctional farms in the Central Pomerania region are characterized by a high level of development differentiation. The level of development depends on the degree of diversification of income sources as well as the period of management of the farm by its owner. The other characteristics related to the agrarian structure of the farms were of marginal importance. Hence, the state's policy on supporting the development of agricultural holdings should focus on activities that will result in expanding the opportunities for diversification of income sources. The article is a part of the discussion on the impact of diversification on rural development, including the development of diversified agricultural holdings.
\end{abstract}

Key words: multifunctionality of farms, development of farms, diversification of sources of income.

JEL code: $013, \mathrm{Q} 12, \mathrm{Q} 14$

\section{Introduction}

Multifunctional rural development refers to the paradigm of economic diversification in the context of the development of non-agricultural functions and non-agricultural employment of the rural population. In socio-economic terms, it refers to the rational management of production factors, while in a spatial context, to the optimal allocation of resources and diversification of economic activity in a rural space (Hopfer A., Bajerowski T., SuchtaJ., 2000; Sikora J., 2012). This process means moving away from monofunctional development based mainly on agricultural production, to create new non-agricultural jobs that contribute to the diversification of income sources in rural areas (Klodzinski M., 1997; Duczkowska-Malysz K., 1993). It is connected with the development of entrepreneurship, mainly in the area of agricultural production services, in the technical and commercial services for the rural area, agri-food processing, investments in infrastructure development, environmental protection, tourism, crafts and industry development and the special sectors of agriculture (Klodzinski M., 1995). The concept of multifunctionality is very broad (Salamon J., 2005). It may include farmers and their households, agriculture as an economic sector or a specific area, i.e. the rural areas (Adamowicz M., Zwolinska-Ligaj M., 2009; Cairol D., et al., 2009). In literature, multifunctionality is considered in microeconomic terms, i.e. in relation to agricultural holdings in which there is a shift of production factors between agricultural and nonagricultural activities. According to M. Adamowicz (2004), the multifunctional farm is one that produces products and services of the following types: a) (market) commodities - agricultural and foodstuffs, processed food, agrotourism, production services and others; b) self-procurements self-supply of food, neighborhood assistance, self-help social services - education and care, care for the elderly and people with disabilities; c) non-market - public goods (food and food security, 
environmental protection and conservation, disaster prevention) and social services (positive and negative external effects, waste recycling, rural landscape, cooperation and social climate).

The aim of the study is to determine the level of development of multifunctional farms and to indicate which factors influence this development, on the example of selected farms in Central Pomerania region. We hypothesized that an important factor influencing the development of multifunctional farms is the level of diversification of income sources, where higher income diversification is associated with an increase in total income of farmers' households and their higher profitability. The level of diversification of income sources was determined on the basis of the number of farm income sources per hectare of agricultural land. The following tasks are set: 1) presentation the concept and the scope of multifunctionality of farms and identification the factors that influence their development; 2) to summarize and evaluate of variables that can explain the differentiation of the level of development of multifunctional farms in Central Pomerania region.

\section{Multifunctionality of agricultural holdings}

The multifunctionality of farms is connected with the phenomenon of multi-employment of farmers and economic diversification of agricultural holdings. Multi-employment involves taking paid off-farm jobs by people engaged in agricultural activities (Wilkin J., 2010; Zmija K., 2016; Blad M., 2013). It means searching for a main non-agricultural source of income. Multifunctional farms can also have social character, which means the holding, while continuing agricultural production for the purpose of self-supply of households, simultaneously provides craft services (Michna W., 2005). Economic diversification of farms can be treated in two ways: firstly, as conducting other business activities linked to the farm, apart from agricultural activity. In this way, it provides a source of support for the core business, as well additional income apart from that of the core business. Secondly, diversification occurs when a given project is undertaken by a farmer instead of the agricultural activity, but by using the components of a farm as its base (LobosKotowska D., Stanko M., 2015). Diversification thus means the mobilization of the following reserves of the farm stemming from: a) obtaining a larger part of the added value to the raw materials produced, through their refinement (through local processing) and direct sale of these products to city dwellers and / or tourists, often called "local product"; (b) the incorporation of the holding into the protected natural and cultural heritage and thereby launching the activities of landscaping and flora and fauna protection, traditional architecture, the cultivation of folklore, providing other people with access to the land, continuation and/or introduction of traditional plants and animals and methods of their cultivation and breeding; (c) the provision of services within the agricultural sector, consisting of the rental of agricultural equipment and / or the provision of services to other farmers, etc.; (d) the provision of outside agricultural services, consisting of the use of own farm resources, including machinery or means of transport, in the sphere of economic, social and communal services (Kaleta A., 2008). It can therefore be stated that diversification increases the strength of farm union with the environment and market, and widens their scope (Babatunde R.O., 2012). According to F. Ellis, diversification of income sources may be a conscious choice or a necessity (Ellis F., 2000). Diversification by choice is a wellthought-out economic strategy aimed at improving living conditions and increase income (Ellis F., 1998). It also contributes to the development of individual farms. Its importance lies in the fact that it significantly removes the demand-side constraints on development and creates a costeffective way to reduce the negative effects of market uncertainty (Wozniak M., 2008). On the 
other hand, the necessity of diversification results first from the need to increase the income of the farmer's family, since the income from farming activities does not ensure the maintenance of farmer's household; secondly, from the active management of the risk of agricultural activity, and thirdly, from the necessity of having additional sources of income in order to increase investment or to secure its implementation in the absence of access to the credit market (Babatunde R.O., 2015).

The developmental potential of multifunctional farms is the result of many factors, exogenous and endogenous. The former consist of the capital and investors, the level of infrastructure development, markets, environmental conditions (climate, terrain), social mentality, involvement of local government, location with respect to economic centres and formal and legal constraints (Smolen M., 2002). Endogenous factors include, first and foremost, farm resources and their efficient use. The potential for diversification increases with the value of assets and their diversification (Schwarze S., Zeller M., 2005). This also applies to access to external financing of development projects, including non-agricultural ones. By diversifying income sources, farms are hedging against the risk of not receiving income from agricultural production (Janvry $A_{\text {., }} M$. Fafchamps A., Sadoulet E., 1991; Kinsey B., Burger K., Gunning J.W., 1998; Mishra A. K., El-Osta H. S., Sandretto C. L., 2004; Zawadzka D., Kurdys-Kujawska A., 2015).

\section{Materials and methods}

The subjects of the study were agricultural farms located in Central Pomerania, which, apart from agricultural activity, obtained income from non-agricultural activities. This region includes Koszalin and Slupsk subregions (total of 15 poviats, including 87 municipalities, including 12 urban gminas, 22 urban-rural gminas, 51 rural gminas and 2 gminas with a city status that have district rights). The analysed units were owners or managers of agricultural holdings. The study was conducted from May to June 2012, using a questionnaire survey. Non-probability sampling was used for selecting samples. The selection of units for the test was a random one, and it also had the character of snowball-sampling. 256 well-filled questionnaires were qualified for the study. In order to determine the degree of variation in the level of development of multifunctional farms, a linear ordering method based on Z. Hellwig's taxonomic measure of development (TMD) was used. Based on literature review as well as the available statistical data, variables have been identified that can explain the variation in the level of development of multifunctional farms. It was assumed that the level of development of multifunctional farms is diversified by factors that can be divided into three categories (1) demographic features of agricultural holdings including farmer's age, farm management period and employment; (2) capital resources, comprising the area of agricultural land and equipment in fixed assets on the farm; (3) socio-economic opportunities including, among others, the degree of diversification of income sources on the farm. Taking into consideration the above assumptions, potential diagnostic variables were created, including: $X_{1}$ - share of arable land in the total area of agricultural land $(\%) ; X_{2}$ - share of meadow and pasture land in the total area of agricultural land $(\%) ; X_{3}$ - share of orchard surface in the total area of agricultural land $(\%)$; $X_{4^{-}}$share of own land in the total area of agricultural land $(\%) ; X_{5}$ - share of leased land in the total area of agricultural land $(\%) ; X_{6}$ - change in the area of agricultural land at the end of 2012 as compared to the end of $2006(\%) ; X_{7}$ - the number of fixed assets in the holding per hectare of agricultural land; $X_{8}$ - the number of people permanently employed on the farm, per hectare of agricultural land; $X_{9}$ - the number of sources of income on the farm, per hectare of agricultural 
land; $X_{10}$ - farmer's age (years) and $X_{11}$ - farm management period (years). The diagnostic variables were statistically verified for the coefficient of variation (the limit of the coefficient of variation was assumed to be 0.1 ) and the correlation coefficient (the threshold for the correlation coefficient was 0.5 ). Variables that were strongly correlated with the others were eliminated. Of the eleven trait characteristics, those traits were included that have a weak association with one another and which represent traits excluded from the study. The final set of diagnostic features is presented in Table 1.

Table 1

The final set of diagnostic variables

\begin{tabular}{|l|l|}
\hline $\mathbf{X 1}$ & share of arable land in the total area of agricultural land ( \%) \\
\hline $\mathbf{X 4}$ & share of own land in the total area of agricultural land ( \%) \\
\hline $\mathbf{X 6}$ & change in the area of agricultural land at the end of 2012 as compared to the end of 2006 ( \%) \\
\hline $\mathbf{X 9}$ & the number of sources of income on the farm, per hectare of agricultural land \\
\hline X11 & farm management period (years) \\
\hline
\end{tabular}

The study assumed that all variables that make up the final set of diagnostic features are stimulants ${ }^{1}$. For variables, basic descriptive statistics were calculated, as shown in Table 2.

Table 2

Basic statistical characteristics of diagnostic variables

Source: authors' study

\begin{tabular}{|l|c|c|c|c|c|}
\hline \multirow{2}{*}{\multicolumn{1}{c|}{ Characteristic }} & \multicolumn{5}{c|}{ Variables } \\
\cline { 2 - 6 } & $\mathbf{X 1}$ & $\mathbf{X 4}$ & $\mathbf{X 6}$ & $\mathbf{X 9}$ & $\mathbf{X 1 1}$ \\
\hline Average & 75.38 & 85.73 & 101.11 & 0.35 & 14.93 \\
\hline Median & 81.82 & 100.00 & 100.00 & 0.17 & 13.00 \\
\hline Minimum & 0.00 & 0.00 & 14.29 & 0.01 & 1.00 \\
\hline Maximum & 100.00 & 100.00 & 233.33 & 2.61 & 45.00 \\
\hline Standard deviation & 25.17 & 30.38 & 17.24 & 0.49 & 9.72 \\
\hline Coefficient of variation & 33.39 & 35.43 & 17.05 & 138.21 & 65.09 \\
\hline
\end{tabular}

An indispensable method when using grouping and ordering methods is the normalization of variables that ensures their comparability. Variables were reduced to comparability using a procedure called unitarisation:

$$
Z_{\text {ij }} \frac{x_{1 j}-x_{f, \min }}{x_{f \max }-x_{f, \min }}
$$

Where:

$z_{\text {ij }}$ - normalized (unitarized) value of the $j$-th variable for the $i$-th object, $x_{j, m i n}=\min _{i} x_{i j}, x_{j, m a x}=$ $\max _{i} x_{i j}$.

Once the diagnostic features have been standardized, the value of the synthetic variable is determined (Salamaga M., 2010):

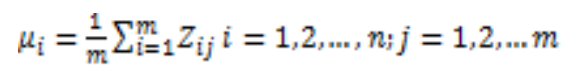

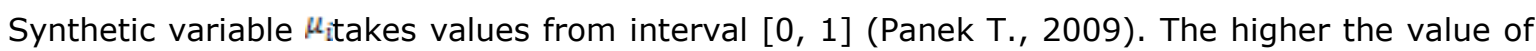
the $\mu_{i}$ meter, the higher the level of development of the examined objects.Once the objects were ordered by value $\mu_{i}$, they were divided into three groups. For this purpose, variable $\mu_{i}$ range was designated:

${ }^{1}$ Stimulants are such variables, whose growing values indicate he increase in the level of the studied phenomenon (development of farms), and so they are a desirable phenomenon (Kukula K., 2000). 


$$
l=\frac{\operatorname{maxp} \mu_{1}-\min \mu_{4}}{a}
$$

Ordered by the value of $\mu_{i}$, multifunctional farms could be divided into three homogenous groups in terms of development ${ }^{1}$ :

$\mathrm{I}: \mu_{\mathrm{i}} \in\left(\operatorname{maxp}_{\mathrm{i}}-l_{i} \max _{\mathrm{i}} \mu_{\mathrm{i}}\right]_{\text {- }}$ highest level of development;

II: $\mu_{\mathrm{i}} \in\left(\max _{\mathrm{i}} \mu_{\mathrm{i}}-2 l \max _{\mathrm{i}} \mu_{\mathrm{i}}-l\right]$. medium level of development;

III: $\mu_{\mathrm{i}} \in\left[\max _{\mathrm{i}} \mu_{\mathrm{i}}-3 l_{i} \max _{i} \mu_{\mathrm{i}}-2 l\right]$ - lowest level of development.

To determine the factors that had the greatest impact on the studied phenomenon, information weights have been used, as $\omega_{\mathrm{i}}$ coefficient:

$$
\omega_{i}=\frac{w_{f}}{\sum_{j=1}^{w} w_{j}}
$$

Where:

$v_{j}$ - is the coefficient of variation of the $j$-th variable.

\section{Research results and discussion}

The analysis shows that the majority of the examined multifunctional farms in Central Pomerania (75.53 \%) have an average level of development (Table 3). Only $11.70 \%$ of analysed multifunctional farms are classified as having the lowest level of development. The remaining farms were characterized by high levels of development.

Table 3

Results of classification of multifunctional farms

\begin{tabular}{|l|c|c|c|c|c|c|}
\hline \multirow{2}{*}{ Class } & \multirow{2}{*}{ Number of farms } & \multicolumn{5}{|c|}{ Average values of diagnostic measures } \\
\cline { 3 - 7 } & & $\mathbf{X 1}$ & $\mathbf{X 4}$ & $\mathbf{X 6}$ & $\mathbf{X 9}$ & $\mathbf{X 1 1}$ \\
\hline I & 13 & 90.25 & 100.00 & 111.53 & 0.65 & 25.18 \\
\hline II & 71 & 78.09 & 89.32 & 99.68 & 0.29 & 14.30 \\
\hline III & 11 & 42.56 & 48.11 & 98.61 & 0.35 & 7.58 \\
\hline
\end{tabular}

Source: authors' study

Multifunctional farms with the highest level of development are characterized by a relatively high share of arable land in the total area of farmland owned by the farmer. In this group of farms, the degree of diversification was the highest. The number of income sources per hectare of farmland $\left(X_{9}\right)$ was 0.65 and was almost double the arithmetic average for all farms. It should be noted that in the group of farms with the highest level of development the processes of concentration of production assets were relatively faster than in other groups. The most significant manifestation of the changes was the increase in the used land at the end of 2012 compared to the end of 2006. In these units, the concentration of agricultural land increased by $11.53 \%$. It can be argued that enlargement of the area in these farms was possible thanks to supplementing incomes from non-agricultural activities. Thus, gaining income from non-agricultural activity may be an alternative means of obtaining funds to finance investments in agricultural holdings. Multifunctional farms with the highest levels of development show above-average farm management period values. This means that the owners of these farms have had considerable experience in managing a farm (average 25 years). They also have more knowledge and skills in recognizing market needs, hence, their increased activity in various areas (agricultural and non-agricultural). In addition, with the prolonged period of farm management, the accumulation of assets increases, which are needed

\footnotetext{
${ }^{1}$ The span of the class divisions was determined on the basis of the constant $I$, determined according to the formula: $1=\frac{7}{x}$ 
to start new ventures. As indicated by the results of the research, the multifunctional farms in the Central Pomerania region are characterized by, for the most part, an average level of development. These units are characterized by a relatively higher share of arable land in the total area of the farm ( $78 \%)$ and the share of land ( $89 \%)$, compared to the arithmetic average for all analysed farms. Variable $X_{11}$ (farm management period) was similar to the mean of all farms analysed. Medium-level agricultural holdings were characterized by the lowest degree of diversification of income sources. The smallest group consisted of multifunctional farms with the lowest level of development. These entities were characterized by a small share of arable land in the total area of agricultural land $(42.56 \%)$, compared to other groups. In these farms, there is a great diversity in the structure of the area used, which makes it possible to diversify the sources of income. In addition, a small share of arable land can mean lower farm income, which further limits access to external sources of funding. This forces the farmer to look for other sources of income. A significant part of the area of agricultural land in these holdings were leased lands. Multifunctional farms classified as the lowest level of development were managed by farmers whose farm management experience is relatively small, averaging 7 years. It can be surmised that these are people working outside agriculture. Their pursuit of agricultural activity may result from succession due to the necessity of discontinuing agricultural activity by parents / in-laws, as this is a precondition for early retirement, supplementary agricultural retirement, periodic agricultural retirement or a disability pension. Analysing the different variables that differentiate the level of development of farms in Central Pomerania, it can be noted that during the analysed period, the development of multifunctional farms was influenced by two factors, i.e. the diversification of income sources $\left(X_{9}\right)$ and the management of the farm $\left(X_{11}\right)$. Other factors that were part of the agrarian structure were less significant (Table 4).

Table 4

Value of $\omega_{i}$ coefficient for all diagnostic characteristics

\begin{tabular}{|l|c|c|c|c|c|}
\hline \multirow{2}{*}{ Specification } & \multicolumn{5}{|c|}{ Variables } \\
\cline { 2 - 7 } & $\mathbf{X 1}$ & $\mathbf{X 4}$ & $\mathbf{X 6}$ & $\mathbf{X 9}$ & $\mathbf{X 1 1}$ \\
\hline Coefficient $\omega_{\mathrm{i}}$ & 0.11 & 0.12 & 0.06 & 0.48 & 0.23 \\
\hline
\end{tabular}

Source: authors' study

\section{Conclusions and suggestions}

1) Multifunctional farms in the Central Pomerania region are characterized by a distinct level of development differentiation.

2) The results show that the capital of a farm, including the size and structure of its assets, the level of diversification of income sources and the management period of the farm, have a significant impact on this diversification.

3) The key factor influencing the level of development of multifunctional farms in the Central Pomerania is the level of income differentiation and the period of management of the farm. Diversification of income in agricultural holdings, including having fixed income from outside of the farm, increases the stability of the farmers' household income and can condition their investment decisions. The period of farm management is directly related to access to its resources. These resources (land, capital, labour) determine the opportunities for non-agricultural activity and the degree of diversification of farm incomes and thus affect the level of development of agricultural holdings. The study results confirm the thesis included in the introduction. 
4) Multifunctional farms have the possibility of rapid develop, but, but then it is imperative to take action on the part of various public institutions to increase the level of diversification of income sources. Major areas of support should focus on reducing barriers for market entry, increasing access to external funding sources, improving rural infrastructure, developing support programs for rural entrepreneurship, and conducting training initiatives to identify opportunities for additional revenue generation and financial management.

The presented results are a contribution to further research in the field of development of multifunctional farms. They can provide a comparative material to study the regionalization of development of multifunctional farms not only in Poland but also in other countries.

\section{Bibliography}

1. Adamowicz, M. (2004). Wielofunkcyjne gospodarstwa rolne jako podmiot w rozwoju wsi i rolnictwa (Multifunctional farms as an entity in the development of the village and agriculture). [in:] Adamowicz M. (ed.). Wiejskie gospodarstwa domowe w obliczu problemow transformacji, integracji i globalizacji (Rural households towards problems of transformation, integration and globalisation). Wydawnictwo Szkoly Glownej Gospodarstwa Wiejskiego, Prace NaukoweKPAiM, 33, Warszawa, p. 30.

2. Adamowicz,M., Zwolinska-Ligaj, M. (2009). Koncepcja wielofunkcyjnosci jako element zrownowazonego rozwoju obszarow wiejskich (The concept of multifuncionality as an element of sustainable development of rural areas). Zeszyty Naukowe Szkoly Glownej Gospodarstwa Wiejskiego w Warszawie. Polityki Europejskie, Finanse i Marketing, 2 (51), p. 18.

3. Babatunde, R.O. (2012). Assessing the Effect of Off-farm Income Diversification on Agricultural Production in Rural Nigeria. ASC Working Paper 106.

4. Babatunde, R.O. (2015). On-farm and Off-farm Works: Complement or Substitute? Evidence from Nigeria.MSM Working Paper 02.

5. Blad, M. (2013). Wielozawodowosc w rodzinach rolniczych w Polsce. Stan i tendencje zmian w latach 20052010 (Pluriactivity in agricultural families in Poland. Status quo and trends of changes in 2005-2010). Zagadnienia Ekonomiki Rolnej, 2 (335), pp. 71-84.

6. Cairol, D., Coudel, E., Knickel, K., Caron, P., Kroger, M. (2009). Mulitifunctionality of Agriculture and Rural Areas as Reflected in Policies: The Importance and Relevance of Territorial View. Journal of Environmental Policy \& Planning, 11:4, pp. 269-289.

7. Duczkowska-Malysz, K. (ed.) (1993). Przedsiebiorczosc na obszarach wiejskich: w strone wsi wielofunkcyjnej (Entrepreneurship in rural areas: towards a multifunctional village). Instytut Rozwoju Wsi i Rolnictwa - PAN, Warszawa, pp. 6-7.

8. Ellis F. (2000). The Determinants of Rural Livelihood Diversification in Developing Countries. Journal of Agricultural Economics, Volume 51, pp. 289-302.

9. Ellis F. (1998). Household Strategies and Rural Livelihood Diversification. The Journal of Development Studies, Volume 35 (1), pp. 1-38.

10. Hopfer, A., Bajerowski, T., Suchta, J. (2000). Mozliwosci wielofunkcyjnego rozwoju obszarow wiejskich polnocno-wschodniej Polski na przykladzie Warmii i Mazur (Possibilities of multifunctional development of rural areas of north-eastern Poland on the example of Warmia and Mazury). [in:] Stasiak A. (ed.). Mozliwosci wielofunkcyjnego rozwoju wsi polskiej w kontekscie integracji z Unia Europejska. Aspekty regionalne (Possibilities of multifunctional development of the Polish countryside in the context of integration with the European Union. Regional aspects). Wydawnictwo Szkoly Glownej Gospodarstwa Wiejskiego, Studia, T. CX, Warszawa, p. 219.

11. Janvry, A., Fafchamps, A.M., Sadoulet, E. (1991). Peasant Household Behavior with Missing Markets: Some Paradoxes Explained. The Economic Journal, 101, pp. 1400-1417.

12. Kaleta, A. (2008). Dywersyfikacja zrodel dochodow ludnosci wiejskiej (Diversification of the income sources of the rural population). Wydawnictwo Uniwersytetu Mikolaja Kopernika, Torun, pp. 54-56.

13. Kinsey, B., Burger, K., Gunning, J.W. (1998). Coping with Drought in Zimbabwe: Survey Evidence on Responses of Rural Households to Risks. World Development, 26 (1), pp. 89-110.

14. Klodzinski, M. (1995). Rozwoj rolnictwa w powiazaniu z wielofunkcyjnoscia terenow wiejskich (The development of agriculture in relation to the multifunctionality of rural areas). [in:] Klodzinski M., Rosner A. (eds.). Rolnictwo w gospodarce Opolszczyzny. Znaczenie, perspektywy, zagrozenia (Agriculture in the economy of the Opole region. Meaning, perspectives, threats). Wydawnictwo Szkoly Glownej Gospodarstwa Wiejskiego, Warszawa, pp. 22-23.

15. Klodzinski, M. (1997). Istota wielofunkcyjnego rozwoju terenow wiejskich(The essence of multifunctional development of rural areas). [in:] Klodzinski M., Rosner A. (eds.). Ekonomiczne i spoleczne uwarunkowania i mozliwosci wielofunkcyjnego rozwoju wsi w Polsce (Economic and social conditions and possibilities of multifunctional rural development in Poland). Wydawnictwo Szkoly Glownej Gospodarstwa Wiejskiego, Warszawa, p. 41.

16. Kukula, K. (2000). Method of Unitarian Unity. PWN, Warsaw. 
17. Lobos-Kotowska, D., Stanko, M. (2015). Dywersyfikacja dzialalnosci rolniczej jako instrument wspierania rozwoju gospodarstwa rodzinnego (na przykladzie agroturystyki) (Diversification of agricultural activity as an instrument to support the development of a family farm (on the example of agritourism). [in:] Litwiniuk p. (ed.), Prawne mechanizmy wspierania i ochrony rolnictwa rodzinnego w Polsce i innych panstwach Unii Europejskiej (Legal mechanisms for supporting and protecting family farming in Poland and other European Union countries). Fundacja Programow Pomocy dla Rolnictwa, FAPA, Warszawa, p. 397.

18. Michna, W. (2005), Zroznicowanie funkcji gospodarstw rolnych w ujeciu przestrzennym. Program wieloletni 2005-2009 (Differentiation of farm functions in spatial terms. Monographs of Multi-annual Programme 2005-2009). Instytut Ekonomiki Rolnictwa i Gospodarki Zywnosciowej- PIB, Warszawa, p. 12.

19. Mishra, A. K., El-Osta, H. S., Sandretto, C. L. (2004). Factors Affecting Farm Enterprise Diversification. Agricultural Finance Review, pp. 151-165.

20. Panek, T. (2009). Statystyczne metody wielowymiarowej analizy porownawczej (Statistical methods of multi-dimensional comparative analysis).Wydawnictwo Szkoly Glownej Handlowej, Warszawa.

21. Salamaga, M. (2010). Mierniki podobienstwa grupowania obiektow (Meters of the similarity of grouping of objects).Wiadomosci Statystyczne, 6(589), Warszawa.

22. Salamon, J. (2005). Badania wielofunkcyjnego rozwoju obszarow wiejskich wojewodztwa swietokrzyskiego (Research on multifunctional development of rural areas of the swietokrzyskie voivodship). Infrastruktura $i$ ekologia terenow wiejskich, 4. Polska Akademia Nauk, Oddzial w Krakowie, pp. 145-155.

23. Schwarze, S., Zeller, M. (2005). Income Diversification of Rural Households in Central Sulawesi, Indonesia. Quarterly Journal of International Agriculture 44, 1, pp. 61-73.

24.Sikora, J. (2012). Wielofunkcyjnosc obszarow wiejskich w Polsce (Multifunctional character of rural areas in Poland). Journal of Agribusiness and Rural Development, Volume 2(24), pp. 215-226.

25. Smolen, M. (2002). Czynniki roznicujace rozwoj gospodarczy gmin w regionie krosnienskim (Factors differentiating the economic development of communes in the Krosno region).Wydawnictwo Uniwersytetu Rzeszowskiego, Rzeszow.

26. Wiklin, J. (2010). Wielofunkcyjnoscrolnictwa - noweujecierolirolnictwa w gospodarce i spoleczenstwie (Multifunctionality of agriculture - a new approach to the role of agriculture in the economy and society). [in:] J. Wiklin (ed.), Wielofunkcyjnosc rolnictwa. Kierunki badan, podstawy metodologiczne i implikacje praktyczne (Multifunctionality of agriculture. Research directions, methodological foundations and practical implications). Instytut Rozwoju Wsi i Rolnictwa - PAN, Warszawa, p. 23.

27. Wozniak, M. (2008). Dywersyfikacja szansa rozwoju indywidualnych gospodarstw rolnych w globalnej gospodarce (Diversification as an opportunity for development of individual agricultural farms in global economy). Zeszyty Naukowe Szkoly Glownej Gospodarstwa Wiejskiego, Ekonomika i Organizacja Gospodarki Zywnosciowej, Nr 67, Warszawa, pp. 15-24.

28. Zawadzka, D., Kurdys-Kujawska, A. (2015). Diversification of Income Sources and their Significance in the Risk Management of Farms. Zeszyty Naukowe Uniwersytetu Szczecinskiego, 855, Finanse, Rynki Finansowe, Ubezpieczenia, 74, pp. 619-628.

29. Zmija, K. (2016). Strategie roznicowania dzialalnosci gospodarczej przez rolnikow posiadajacych drobne gospodarstwa rolne (Strategies for business activities diversification implemented by farmers possessing small farms). Roczniki Naukowe Stowarzyszenia Ekonomistow Rolnych i Agrobiznesu, Volume XVIII, Issue 3, pp. $419-425$. 